\title{
Self-reported adherence to highly active antiretroviral therapy in a tertiary hospital in Nigeria
}

\author{
Ekiuwa V. Eribo ${ }^{1}$ and Omokhoa A. Adeleye ${ }^{2}$ \\ Ghana Med J 2020; 54(1): 30--35 DOI: http://dx.doi.org/10.4314/gmj.v54i1.5
}

\author{
${ }^{1}$ Department of Pharmacy, University of Benin Teaching Hospital, Benin City, Nigeria \\ ${ }^{2}$ Department of Community Health, University of Benin Teaching Hospital, Benin City, Nigeria
}

Corresponding author: Omokhoa A. Adeleye

E-mail: adeleyeoa@gmail.com

Conflict of interest: None declared

\section{SUMMARY}

Background: Non-adherence to highly active antiretroviral therapy (HAART) favours drug resistance and wastes resources. These have negative implications for personal and public health.

Objective: To assess adherence levels, the associated factors and its association with increase in CD4 cell count in people living with HIV (PLHIVs).

Methods: In a cross-sectional survey, systematically selected adult PLHIVs attending a tertiary hospital in Nigeria self-reported their 28-day adherence to HAART and reasons for missing doses using an interviewer-administered questionnaire. Their 6-month difference in CD4 cell count was also assessed.

Results: The participants totalled 425. Their mean age was 38.6 (SD, 10.1) years and 309 (72.7\%) had secondary or tertiary education. The 28-day mean adherence level was $96.8 \%$ (SD, $7.9 \%$ ) and 354 (83.3\%) participants had optimal adherence $(\geq 95 \%)$. Socio-demographic characteristics, side effects and having human reminders were not associated with adherence level, but $100 \%$ adherence level since placement on HAART was positively associated with a 6 -month increase in CD4 cell count $(p<0.01 ; \mathrm{OR}=1.87,95 \% \mathrm{CI}=1.21-2.89)$. Reasons given by 156 respondents for missing doses included being too busy, 100 (64.1\%), forgetting, 85 (54.5\%) and sleeping off, 42 (26.9\%).

Conclusion: Mean adherence was high and the majority of participants had optimal adherence. "Never missing a dose" was associated with improved CD4 cell counts, indicating better prognosis. Socio-demographic factors, side effects and human reminders were not associated with an increase in adherence. However, as there is no evidence that adherence improvement measures are detrimental, their use is still recommended.

Keywords: Medication adherence, HAART, HIV, drug resistance, Nigeria, Funding: None declared

\section{INTRODUCTION}

Efforts in support of optimal and efficient use of antiretroviral (ARV) drugs are justified because of the huge resources expended to make ARVs user-fee-free and available, and the clinical and socioeconomic benefits of their use. ${ }^{1}$ Ensuring adherence to highly active antiretroviral therapy (HAART) is one clinical and behavioural strategy to ensure that people living with HIV/AIDS (PLHIV) get utmost benefit from the treatment and that other persons are not at risk of new infections with multidrug-resistant strains of HIV. ${ }^{2}$ Drug resistance and resource wastage have negative implications for personal and public health. Several reports have shown that a level of adherence of at least $95 \%$ is needed to keep the viral load to an undetectable level and for optimal therapeutic benefits. ${ }^{3-6}$ This level has widely been used as the threshold level for determining adherence to HAART.
Self-reported adherence in a study in Calabar, Nigeria, was $59.9 \%$ and the main reasons for skipping doses were a busy schedule, forgetting and a feeling of depression. ${ }^{7}$ In a study in Kenya, $82.1 \%$ of PLHIVs self-reported adherence to HAART. Their commonest reasons for missing a dose included being busy and forgetting. ${ }^{8}$ Identifying the factors associated with non-adherence and reasons for skipping doses provide opportunities for interventions to improve adherence to HAART. This study was therefore conducted to assess the level of adherence to HAART, its determinants and its association with increase in CD4 cell count. 


\section{METHODS}

\section{Study setting}

The study was carried out in University of Benin Teaching Hospital (UBTH), Benin City, Edo State, Nigeria. The hospital is a tertiary facility that serves populations in Edo and Delta States and beyond. The antiretroviral therapy (ART) programme is supported by grants from the U.S. President's Emergency Plan for AIDS Relief (PEPFAR). HAART regimens were scheduled as two doses daily. Outpatient clinic visits are scheduled at intervals varying from 2 to 12 weeks. Inadequate hospital ARV stocks and patents' need for frequent follow-up visits favoured short-interval appointments.

Sufficient ARVs are given to cover for every scheduled interval, with allowance made for additional pills. As part of their clinical care, but not for the purpose of this study, PLHIV are requested to attend each clinic appointment with unused pills, but this is commonly not done.

\section{Study population, sample size and sampling}

The target population consisted of PLHIV, aged 18 years and above on HAART attending the consultant outpatient clinic of UBTH. To be included as a participant, a PLHIV should have been on HAART for at least 6 months. PLHIVs with cognitive impairment were excluded. PLHIVs with cognitive impairment were so assessed by their physicians and excluded by their admission to the wards. Cognition was assessed by assessing consciousness, orientation, memory and attention.

The minimum sample size, $n$, for the study was determined using the Cochran formula $\left[n=\mathrm{Z}_{\alpha}{ }^{2} \mathrm{pq} / \mathrm{d}^{2}\right] ;{ }^{9}$ where $Z_{\alpha}$ is the standard normal deviate, taken as 1.96 at an $\alpha$ level of $0.05 ; \mathrm{p}$ is the proportion to be measured in the population, taken as the proportion of PLHIVs who had optimal adherence to HAART $(59.9 \%)$ in a study in Calabar, Nigeria; ${ }^{7} \mathrm{q}=1-\mathrm{p}$; and $\mathrm{d}$ is the error margin tolerated, chosen as $5 \%$. The computed value of $n$ is 369.1 . When allowance is made for persons who may not consent, a $10 \%$ addition yields an adjusted minimum sample size of 407.

Participant recruitment and the interview lasted for 5 weeks, each having 5 working days (Monday to Friday). Pharmacy attendance load was about 48 - 60 PLHIVs daily for collection of prescribed ARVs. With this as a guide, systematic sampling technique, with a sampling interval of 1 in 3, was used to select and interview 18 to 24 PLHIVs daily at the pharmacy, with allowance made for persons who would decline consent.

\section{Ethical Approval}

Ethical approval for the study was granted by UBTH Ethics Committee (Ref EX/MPH/10/10/25). Data were collected only from and on those PLHIV who gave consent to participate in the study.

\section{Measures and data collection}

A pretested interviewer-administered structured questionnaire was used to collect data from which independent and dependent measures were derived. Independent measures included socio-demographic variables (age, sex, educational level, occupation, marital status, religion) whether the respondents reported side effects of the antiretrovirals (ARVs) and whether they had a human reminder for their medications. Respondents were also asked if they missed a dose of ARVs since they commenced therapy and to select their reasons from a list provided, with an open-ended allowance for other reasons.

For each respondent, the per cent adherence (adherence level) was computed as shown below.

Percent adherence over the last 28 days
$=\frac{\# \text { of doses that should have been taken }-\# \text { of doses missed }}{\# \text { of doses that should have been taken }}$
$\times 100 \%$

Optimal adherence was defined as $\geq 95 \%$ for the 28 -day period preceding the interview and suboptimal adherence as $<95 \%$. The mean adherence for the sample was also computed along with its standard deviation. Participants' CD4 cell counts in the most recent 6-month period were obtained from their laboratory reports. The count at the beginning of the period was subtracted from the count at the end to find out if there was an increase.

\section{Data analysis}

Collected data were entered into SPSS version 16 which was used for analysis. Two levels of associations were tested. First, the association between independent measures and optimal adherence was tested. Optimal adherence and having never missed a dose of ARVs were tested for association with an increase in CD4 count. Fisher's exact test was used to test for association. Interval estimates for the associations tested were generated by computing $95 \%$ confidence intervals (CIs) with the aid of COMPARE2 in WinPepi ${ }^{\circledR}$ (Computer Programs for Epidemiologists) version 11.10. The level of significance was set at $p<0.05$ and a $\mathrm{CI}$ that excludes the null value of 1.0 .

\section{RESULTS}

The study participants totalled 425 . Their mean age was 38.6 (SD, 10.1) years. As shown in Table 1, more than two-thirds, 293 (68.9\%), were females and about half, 224 (52.7\%), were married. 
Majority had either secondary, 174 (40.9\%), or tertiary, $135(31.8 \%)$ level of education.

Table 1 Socio-demographic characteristics $\mathrm{N}=425$

\begin{tabular}{|l|l|}
\hline Variables & Frequency (\%) \\
\hline Age (years) & $240(56.5)$ \\
\hline $\mathbf{2 0 - 3 9}$ & $174(40.9)$ \\
\hline $\mathbf{4 0 - 5 9}$ & $11(2.6)$ \\
\hline 60 \& above & \\
\hline Sex & $132(31.1)$ \\
\hline Male & $293(68.9)$ \\
\hline Female & \\
\hline Marital status & $224(52.7)$ \\
\hline Married & $92(21.6)$ \\
\hline Single & $75(17.6)$ \\
\hline Widowed & $34(8.0)$ \\
\hline Divorced & \\
\hline Educational status & $13(3.1)$ \\
\hline None & $103(24.2)$ \\
\hline Primary & $174(40.9)$ \\
\hline Secondary & $135(31.8)$ \\
\hline Tertiary & \\
\hline Occupation & $160(37.6)$ \\
\hline Traders/businesspersons & $68(16.0)$ \\
\hline $\begin{array}{l}\text { Senior civil servants (teachers, adminis- } \\
\text { trators, etc) }\end{array}$ & $18(4.2)$ \\
\hline $\begin{array}{l}\text { Artisan (tailors, hairdressers, carpenters, } \\
\text { drivers, mechanics, etc) }\end{array}$ & $65(15.3)$ \\
\hline $\begin{array}{l}\text { Junior civil servants (clerical officers, se- } \\
\text { curity men, ward orderlies, etc) }\end{array}$ & $31(7.3)$ \\
\hline Students & $7(1.6)$ \\
\hline Soldiers and policemen & $13(3.1)$ \\
\hline Farmers & $13(3.1)$ \\
\hline Other occupations & $11(2.6)$ \\
\hline Unemployed & $47(11.1)$ \\
\hline Religion & $400(94.1)$ \\
\hline Christianity & \\
\hline Islam & \\
\hline African traditional religion and others & \\
\hline
\end{tabular}

As shown in Table 2, 354 (83.3\%) reported optimal adherence. The mean adherence level was $96.8 \%$ (SD, $7.9 \%$ ). The table also shows the corresponding number of participants for every $10 \%$ range of adherence levels. Of the 71 participants with suboptimal adherence, 22 (31.0\%) had adherent levels $>90.0 \%$ (not tabulated).

Table 2 Adherence characteristics $\mathrm{N}=425$

\begin{tabular}{|c|c|c|}
\hline \multicolumn{3}{|l|}{ ures } \\
\hline \multicolumn{3}{|c|}{ Optimal adherence $*=354(83.3 \%)$} \\
\hline \multicolumn{3}{|c|}{ Mean adherence $=96.8 \% ;$ SD $=7.9 \%$} \\
\hline \multicolumn{3}{|c|}{ Pattern of adherence level in the last 28 days } \\
\hline Adherence level in \% & Frequency $(\%)$ & $\begin{array}{l}\text { Cumulative } \\
\text { frequency } \\
(\%)\end{array}$ \\
\hline $50.0-59.9$ & $3(0.7)$ & $3(0.7)$ \\
\hline $60.0-69.9$ & $7(1.6)$ & $10(2.4)$ \\
\hline $70.0-79.9$ & $14(3.3)$ & $24(5.6)$ \\
\hline $80.0-89.9$ & $25(5.9)$ & $49(11.5)$ \\
\hline $90.0-99.9$ & $65(15.3)$ & $114(26.8)$ \\
\hline 100.0 & $311(73.2)$ & $425(100.0)$ \\
\hline
\end{tabular}

Of the 156 who reported missing a dose (Fig 1), the commonest reasons stated were being too busy, 100 (64.1\%), and forgetting to take medications, $85(54.5 \%)$. Nineteen $(12.2 \%)$ said that they ran out of drugs.

Feeling depressed, 7 (4.5\%), and the perception that taking the drug was stigmatising, $4(2.6 \%)$ were the emotion-related reasons reported for missing a dose.

CD4 cell count results of 409 (96.2\%) participants were found. Increase in CD4 cell count (Table 3) over a period of 6 months was not associated with optimal adherence.

Table 3 Adherence and increase in CD4 cell count $\mathrm{n}=$ 409*

\begin{tabular}{|c|c|c|c|c|}
\hline \multirow{2}{*}{$\begin{array}{l}\text { Adherence } \\
\text { characteristics }\end{array}$} & \multicolumn{2}{|c|}{ Increase in CD4 cell count } & \multirow[t]{2}{*}{ OR $(95 \%$ CI $)$} & \multirow[t]{2}{*}{ p-value } \\
\hline & $\begin{array}{l}\text { Yes }(\%) \\
n=251(61.4)\end{array}$ & $\begin{array}{l}\text { No }(\%) \\
n=158(38.6)\end{array}$ & & \\
\hline \multicolumn{5}{|c|}{ Optimal adherence } \\
\hline Yes & $219(63.3)$ & $127(36.7)$ & 1.0 & \multirow[t]{2}{*}{0.06} \\
\hline No & $32(50.8)$ & $31(49.2)$ & $1.7(1.0-2.9)$ & \\
\hline \multicolumn{5}{|c|}{ Never missed a dose of HAART } \\
\hline Yes & $176(66.7)$ & $88(33.3)$ & 1.0 & \multirow[t]{2}{*}{$<0.01$} \\
\hline No & $75(51.7)$ & $70(48.3)$ & $1.9(1.2-2.9)$ & \\
\hline
\end{tabular}

*Number of participants whose results were available

However, increase in cell count was observed in $66.7 \%$ of respondents who reported never missing a dose compared to $51.7 \%$ of those who did not $(p<0.01 ; \mathrm{OR}=1.9$, $95 \% \mathrm{CI}=1.2-2.9)$. As shown in Table 4 , there was no statistically significant difference between proportions of participants who had $\geq 95 \%$ adherence across the different categories of the variables tested.

\section{DISCUSSION}

This study found that the majority of participants had adequate adherence to HAART and that there are important gaps that indicate opportunities for improvement. That $83.3 \%$ of respondents in the study population had optimal adherence was good, but this was lower than $97 \%$ reported in Kano. ${ }^{10}$ This percentage was, nevertheless, higher than $63 \%$ reported in Ibadan ${ }^{11}$ and $60 \%$ reported in Calabar, ${ }^{7}$ but similar to $82 \%$ reported in a Kenyan study. ${ }^{8}$ Thus, adherence to HAART in the study population is broadly within the range reported in Nigeria.

Assessing, monitoring and early detection of non-adherence at the individual patient level, as illustrated in this study, are important because they provide them with an opportunity for a prompt intervention to obviate the challenges associated with treating resistant HIV infection, including the increased risk of treatment failure, complications, additional health service demand and early death. 
These consequences of non-adherence, as public health challenges, also include the deployment of additional resources, which implies that fewer resources will be available for other needs in and outside the health system. These issues have been similarly examined in other publications. ${ }^{12,13}$

Table 4 Distribution of adherence to HAART by respondents' characteristics

\begin{tabular}{|c|c|c|c|c|c|c|}
\hline \multirow[t]{2}{*}{ Variables } & \multirow[t]{2}{*}{ Categories } & \multirow{2}{*}{$\begin{array}{l}\text { Total }(\%) \\
\mathrm{N}=425(100.0)\end{array}$} & \multicolumn{2}{|c|}{ Optimal adherence } & \multirow[t]{2}{*}{ OR $(95 \% \mathrm{CI})$} & \multirow[t]{2}{*}{ p-value } \\
\hline & & & $\begin{array}{l}\text { Yes }(\%) \\
n=354(83.3)\end{array}$ & $\begin{array}{l}\text { No }(\%) \\
n=71(16.7)\end{array}$ & & \\
\hline \multirow[t]{2}{*}{ Age in years } & $20-39$ & $240(56.5)$ & $203(84.6)$ & $37(15.4)$ & 1.0 & \multirow[t]{2}{*}{0.43} \\
\hline & 40 and above & $185(43.5)$ & $151(81.6)$ & $34(18.4)$ & $1.2(0.7-2.1)$ & \\
\hline \multirow[t]{2}{*}{ Sex } & Male & $132(31.1)$ & $107(81.1)$ & $25(18.9)$ & 1.0 & \multirow[t]{2}{*}{0.40} \\
\hline & Female & $293(68.9)$ & $247(84.3)$ & $46(15.7)$ & $0.8(0.5-1.4)$ & \\
\hline \multirow[t]{2}{*}{ Educational level } & $\begin{array}{l}\text { No formal \& } \\
1^{0}\end{array}$ & $116(27.3)$ & $103(88.8)$ & $13(11.2)$ & 1.0 & \multirow[t]{2}{*}{0.08} \\
\hline & $2^{0}$ and $3^{0}$ & $309(72.7)$ & $251(81.2)$ & $58(18.8)$ & $1.8(0.9-3.8)$ & \\
\hline \multirow[t]{3}{*}{ Marital status } & Single & $92(21.6)$ & $76(82.6)$ & $16(17.4)$ & 1.0 & \multirow[t]{3}{*}{0.17} \\
\hline & Married & $224(52.7)$ & $181(80.8)$ & $43(19.2)$ & $1.1(0.6-2.3)$ & \\
\hline & Others* & $109(25.6)$ & $97(89.0)$ & $12(11.0)$ & $0.6(0.21 .4)$ & \\
\hline \multirow[t]{2}{*}{ Religion } & Christianity & $400(94.1)$ & $334(83.5)$ & $66(16.5)$ & 1.0 & \multirow[t]{2}{*}{0.59} \\
\hline & Others** & $25(5.9)$ & $20(80.0)$ & $5(20.0)$ & $1.3(0.4-3.6)$ & \\
\hline \multirow{2}{*}{$\begin{array}{l}\text { Reported at least } \\
\text { one side effect }\end{array}$} & Yes & $290(68.2)$ & $237(81.7)$ & $53(18.3)$ & 1.0 & \multirow[t]{2}{*}{0.26} \\
\hline & No & $135(31.8)$ & $117(86.7)$ & $18(13.3)$ & $0.7(0.4-1.3)$ & \\
\hline \multirow{2}{*}{$\begin{array}{l}\text { Having human } \\
\text { reminders for } \\
\text { their medications }\end{array}$} & Yes & $70(16.5)$ & $60(85.7)$ & $10(14.3)$ & 1.0 & \multirow[t]{2}{*}{0.73} \\
\hline & No & $355(83.5)$ & $294(82.8)$ & $61(17.2)$ & $1.2(0.6-2.9)$ & \\
\hline
\end{tabular}

OR: odds ratio. CI: confidence interval. $1^{0}$ : primary. $2^{0}$ : secondary. $3^{0}$ : tertiary.

*Others: separated, divorced, widowed. **Others: Islam, African traditional religion etc.

The top three reasons for missing a dose of ART in this study were being busy, forgetting to take the drugs and sleeping off. These reasons are quite similar to those found in other Nigerian studies, although the absolute and relative weightings differ. In the Calabar study, the top three reasons were being busy, forgetting to take the drugs and depression. ${ }^{7}$ In the Ibadan study, these were forgetting to take the drugs, wanting to avoid side effects and being away from home. ${ }^{11}$ Forgetting, being away from home and being too busy were the commonest three in a study in Jos. ${ }^{14}$ Other reasons reported by the PLHIVs in this study included running out of drugs (because they missed clinic appointments at which time ART drugs are replenished), falling sick and feeling depressed. Many of the reasons call for support for PLHIVs to improve adherence and also indicate required content for individual public health interventions.
The study showed that optimal adherence level was not associated with socio-demographic variables, self-reported side effects and having human reminders. This implies that non-adherence cuts across categories of these variables non-differentially and that interventions should similarly cut across. However, studies have not been consistent in this regard. Similar to the findings in this study, a Calabar study found that age, sex, educational level, occupation and marital status were not associated with adherence. ${ }^{7}$ In a study in Keffi, age and sex were not associated with adherence. ${ }^{15}$ In a Jos study, sex and occupation were not associated with adherence. ${ }^{14}$ Some studies have shown an association between age and adherence. $8,14,16,17$ These variations further emphasise the need to factor in individual population characteristics in developing interventions to improve adherence to HAART. 


\section{Original Article}

Never missing a dose of HAART in the minimum of 6 months of therapy in this study was associated with a rise in CD4 cell count.

The literature associates optimal adherence with a rise in CD4 cell count and treatment success. ${ }^{18,19}$ The association between increase in CD4 cell count and never missing a dose of HAART appears to underscore a need to motivate PLHIVs to strive towards $100 \%$ adherence level as a highly desirable ideal. In a related Kenyan study, the authors found that a significantly higher proportion of HAART-adherent PLHIVs had CD4 cell counts $>200$ compared to the non-adherents. ${ }^{8}$

The absence of statistical significance in most tests of associations in this study must be understood with caution. For example, while the difference observed with the use of human reminders lacked statistical significance in this study, this does not rule out their clinical and public health significance. Indeed, it is possible that, without reminders, optimal adherence would have been statistically significantly lower among those who need them, suggesting that the use of reminders may have aided adherence to a level that eliminated a statistically significant difference compared to others.

The preponderance of females (68.9\%) in this study population has been similarly observed in previous Nigerian studies such as studies in Calabar (68.6\%), ${ }^{17}$ Makurdi $(64.7 \%),{ }^{20}$ and Abuja (60.2\%). ${ }^{21}$ This mainly reflects women's closer access to HIV screening services through ANC services and therefore, greater likelihood of receiving treatment. Female preponderance in study populations of adherence studies may limit the generalisability of adherence study findings in planning for PLHIV populations because of the sex distribution discordance.

The method used to assess patients' adherence in this study - patients' self-report - deserves some remarks. It has been shown to be affected by recall and social desirability bias..$^{22}$ On the other hand, pharmacy adherence measures (PAMs, such as medication possession ratio, pill count and pill pick-up), ${ }^{23}$ microelectronic monitoring systems (such as MEMS caps) monitoring of plasma drug levels and viral load have been shown to be more objective surrogates of pill-taking behaviour. ${ }^{19}$ Nevertheless, self-report is simple, ${ }^{23}$ and low-cost. ${ }^{24}$ It has also been shown in some studies to be comparable to PAMs in demonstrating association with virological response $e^{25-27}$ and to correlate well with CD4 count and viral load. ${ }^{28}$

The overall significance of this study is that it updates existing data on the pattern of adherence to ARVs in Nigeria, particularly in a tertiary facility setting.
Furthermore, the association demonstrated between adherence level and increase in CD4 cell count provides additional data on immunological response as a means of monitoring and evaluating adherence to ARVs.

The self-reported reasons for skipping doses and the adherence gaps identified can also inform interventions programmes.

Despite the strengths of this study, it has some limitations. Participants' self-reports used to assess adherence in this study implies that their responses may have suffered recall bias. Their frequent failure to present residual pills at clinic visits as required impeded opportunities to verify their self-reports. The limitation conferred by a predominantly female study population has been pointed out.

\section{CONCLUSION}

This study provides additional data on adherence to HAART in Nigeria, the levels of which differ widely from place to place. The mean adherence level and the percentage with optimal adherence were high. Never missing a dose was associated with increased CD4 cell counts, indicating better prognosis. Being busy and forgetfulness were major self-reported reasons for skipping doses. The need for improvement runs across all categories of socio-demographic characteristics.

\section{ACKNOWLEDGEMENT}

The authors are grateful to the patients for their participation in the study.

\section{REFERENCES}

1. Mussa AH, Pfeiffer J, Gloyd SS, Sherr K. Vertical funding, non-governmental organizations, and health system strengthening: perspectives of public sector health workers in Mozambique. Hum Resour Health. 2013;11:26. doi: 10.1186/1478-4491-11-26.

2. Boulle A, Ford N. Scaling up antiretroviral therapy in developing countries: what are the benefits and challenges? Sex Transm Infect. 2007;83:503-5. doi: 10.1136/sti.2007.027748

3. Remien RH, Bastos FI, Terto Jnr V, Raxach JC, Pinto RM, Parker RG et al. Adherence to antiretroviral therapy in a context of universal access, in Rio de Janeiro, Brazil. AIDS Care. 2007;19(6):740-8.

4. McPherson-Baker S, Jones D, Duran R, Klimas N, Schneiderman N. Development and implementation of a medication adherence training instrument for persons living with HIV (The MATI). Behav Modif. 2005;29(2):286-317.

5. Amico KR, Toro-Alfonso J, Fisher JD. An empirical test of the information, motivation and behavioural 
skills model of antiretroviral therapy adherence. AIDS Care. 2005;17(6):661-73.

6. Weiser S, Wolfe W, Bangsberg D. Barriers to Antiretroviral Adherence to patients living with HIV infection and AIDS in Botswana. $J$ Acquir Immune Defic Syndr. 2003;34(3):281-8.

7. Oku AO, Owoaje ET, Ige OK, Oyo-ita A. Prevalence and determinants of adherence to HAART amongst PLHIV in a tertiary health facility in southsouth Nigeria. BMC Infect Dis. 2013;13:401.

http://www.biomedcentral.com/1471-2334/13/401

Accessed 10 Nov, 2013.

8. Wakibi SN, Ng'ang'a ZW, Mbugua GG. Factors associated with non-adherence to highly active antiretroviral therapy in Nairobi, Kenya. AIDS Res Ther. 2011;8:43,

http://www.aidsrestherapy.com/content/8/1/43 Accessed 10 Nov, 2013.

9. Cochran WG. Sampling techniques. Third Ed. New York: Wiley; 1977. p. 75-76.

10. Habib AG, Shepherd JC, Eng MK, Babashani M, Jumare J, Yakubu U et al. Adherence to antiretroviral therapy (ART) during Muslim Ramadan fasting. AIDS Behav. 2009;13(1):42-5.

11. Olowookere SA, Fatiregun AA, Akinyemi JO, Bamgboye AE, Osagbemi GK. Prevalence and determinants of nonadherence to highly active antiretroviral therapy among people living with HIV/AIDS in Ibadan, Nigeria. J Infect Dev Ctries. 2008;2(5):369-72.

12. Munakata J, Benner JS, Becker S, Dezii CM, Hazard EH, Tierce JC. Clinical and economic outcomes of nonadherence to highly active antiretroviral therapy in patients with human immunodeficiency virus. Medical Care. 2006;44(10):893-9.

13. Flessa S, Marschall P. Socio-economic impact of antiviral intervention. Handb Exp Pharmacol. 2009;(189):347-74.

14. Falang KD, Akubaka P, Jimam NS. Patient factors impacting antiretroviral drug adherence in a Nigerian tertiary hospital. J Pharmacol Pharmacother. 2012;3(2):138-42.

15. Pennap GR, Abdulahi U, Bako IA. Adherence to highly active antiretroviral therapy and its challenges in people living with human immunodeficiency virus (HIV) infection in Keffi, Nigeria. $J$ AIDS HIV Res. 2013:5(2):52-8.

16. Murphy DA, Marelich WD, Hoffman D, Steers WN. Predictors of antiretroviral adherence. AIDS Care. 2004;16(4):471-84.

17. Penedo FJ, Gonzalez JS, Dahn JR, Antoni M, Malow $\mathrm{R}$, Costa $\mathrm{P}$ et al. Personality, quality of life and HAART adherence among men and women living with HIV/AIDS. J Psychosom Res. 2003;54(3):2718.

18. Sule WF, Sani ES. CD4+ T cell response to lamivudine, stavudine and nevirapine in human immunodeficiency virus infected antiretroviral-naive men in Nigeria. Indian J Virol. 2011;22(2):90-7.

19. Machtinger EL, Bangsberg DR. Adherence to HIV antiretroviral therapy. 2005.

$\mathrm{http} / /$ hivinsite.ucsf.edu/InSite?page $=\mathrm{kb}$ 00\&doc $=\mathrm{kb}-03-02-09$ Accessed 17 Jan 2016.

20. Shaahu V, Lawoyin T, Sangowawa A. Adherence to highly active antiretroviral therapy (HAART) at a Federal Medical Centre. Afr $J$ Med Sci. 2008;37(1):29-36.

21. Agu KA, Okojie O, Oqua D, King RC, Omonaiye O, Onuoha $\mathrm{C}$ et al. Medication adherence and risk factors for non-adherence among patients taking highly active antiretroviral therapy. West Afr $J$ Pharm. 2011;22(1):19-26.

22. Bangsberg DR. Preventing HIV antiretroviral resistance through better monitoring of treatment adherence. J Infect Dis. 2008;197(Suppl. 3):S272-8.

23. McMahon JH, Jordan MR, Kelley K, Bertagnolio S, Hong SY, Wanke CA et al. Pharmacy adherence measures to assess adherence to antiretroviral therapy: review of the literature and implications for treatment monitoring. Clin Infect Dis. 2011;52(4):493-506.

24. Monjok E, Smesny A, Okokon IB, Mgbere O, Essien J. Adherence to antiretroviral therapy in Nigeria: An overview of research studies and implications for policy and practice. HIV/AIDS - Res Palliat Care. 2010;2:69-76.

25. Weidle PJ, Wamai N, Solberg P, Liechty C, Sendagala $\mathrm{S}$, Were $\mathrm{W}$ et al. Adherence to antiretroviral therapy in a home-based AIDS care programme in rural Uganda. Lancet. 2006;368(9547):1587-94.

26. Fairley CK, Permana A, Read TR. Long-term utility of measuring adherence by self-report compared with pharmacy record in a routine clinic setting. HIV Med. 2005;6(5):366-9.

27. Grossberg R, Zhang Y, Gross R. A time-to-prescription-refill measure of antiretroviral adherence predicted changes in viral load in HIV. J Clin Epidemiol. 2004;57(10):1107-10.

28. Idigbe EO, Adewole TA, Eisen G, Kanki P, Odunukwe NN, Onwujekwe DI et al. Management of HIV-1 infection with combination of Nevirapine, Stavudine, and Lamivudine; a preliminary report on the Nigerian antiretroviral program. $J$ Acquir Immune Defic Syndr. 2005;40(1):65-9. 